\title{
An Internal Analysis of E-Learning Implementation Readiness: Present Evaluation and Future Planning
}

\author{
Ana Rosida ${ }^{1}$, Sri Adrianti Muin ${ }^{2}$, Wahyuni Sakka ${ }^{3}$ \\ ${ }^{1,2}$ Fajar University, Makassar, Indonesia, 90231 \\ ${ }^{3}$ STIE Yapman Majene, West Sulawesi, Indonesia, 90000 \\ ann.rosyed@gmail.com
}

\begin{abstract}
Received : 2020-12-15
Revised : 2021-03-21

Accepted : 2021-03-24
\end{abstract}

ARTICLE HISTORY

\section{KEYWORDS}

E-Learning

E-learning Readiness

Aydin and Tasci Model

Lecturers and Students

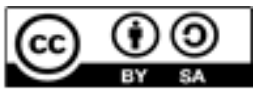

\begin{abstract}
This study aims to see and analyze the readiness of Economic and Social Sciences Faculty of Fajar University to implement E-Learning based on the four factors by using Aydin \& Tasci's ELR Model, namely; people, technology, self-development, and innovation factor. This quantitative study used questionnaire was given to lecturers, and students with the total sample were 185 . The average score of 3.41 is the minimum score for the level of readiness to implement e-learning. Based on the data, it found that lecturers obtained a total score $\bar{x}=3.60$ and students was $\bar{x}=$ 3.40. From four factors for lecturers, self-development factor was the only factor considered unprepared for implementing e-learning which needs some of the work to reach ready category. However, the rest of the factors are in the ready category in the teaching process. On the other hand, students score result indicated not ready to implement e-learning in the learning process. Even though in technology and innovation factors were showing un-readiness, in people factors and selfdevelopment indicated that students are ready to implement e-learning even though it requires a few improvements. From the final score result for both lecturers and students, the data show that Economic and Social Sciences Faculty Fajar University is ready to implement e-learning in teaching and learning process even needs a few improvements.
\end{abstract}

\section{Introduction}

Since 2008, Fajar University has an organizational strategic plan to become one of the leading private universities in eastern Indonesia even at the national level. The form of effort is to follow each year of education development. One of the efforts of this university in the 21 st century is the plan to implement elearning in the teaching and learning process. The institution realizes that the growing development of information technologies has had a significant impact on peoples in various fields, especially in education. Through the use of information technology, it offers unlimited access. One of the uses of information technology is learning called e-learning (Angraini \& Suryadi, 2015).

E-learning will impact the effectiveness of learning in terms of time, place and facilitate interaction between students and lecturers and fellow students. Also, students can share information, can be used as a support for discussion and can access the teaching material at any time, so that students can further strengthen their mastery of the learning material (Rahamma \& Nadjib, 2015). Through information technology-based learning, students are more active in learning activities and make

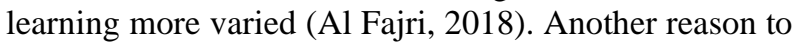
conduct e-learning is a significant increase in the number of university students, the generational change of student population, and the up-to-date nature of online sources that cannot possibly be ignored (Putri, Hamuddin, Nursafira, \& Derin, 2020). Therefore, online learning and teaching system should be conducted in the university and should get the measurement of readiness for the university to implement e-learning in the classroom. Learning systems that use e-learning are different from previous learning systems, learning using e-learning requires preparation both in terms of infrastructure and technical capabilities of potential users (Aydin \& Tasci, 2005). Therefore, every university that wants to 
implement a learning system using e-learning should pay attention to preparation before implementing it.

The readiness to implement e-learning is known as Elearning Readiness (ELR). ELR is an analysis conducted on the e-learning system at the University. The e-learning readiness measurement is implemented so that the organization can quantitatively determine its readiness level so that institutions can determine what policies or strategies will be determined.

The measurement of e-learning readiness is based on the model used, so selecting the e-learning readiness component as the basis for building the model becomes the benchmark for measuring e-learning readiness. The e-learning readiness model is not just limited to preimplementation preparation, but can also be used for organizations that have implemented e-learning. So, the results of this assessment can be used as a basis for making improvements during the next development period. Several factors can be used as benchmarks for the preparation for the implementation of e-learning, namely people factors, self-development factors, technological factors and innovation factors of the e-learning model by Aydin \& Tasci (Aydin \& Tasci, 2005).

This research should be carried out so that the research results can be considered by institutions in the implementation of e-learning as a form of evaluation. These considerations aim to ensure that e-learning can be applied correctly and can be used as a basis for making improvements for future planning.

Seeing the current pandemic Corona Virus 19 phenomena starting in 2020 makes all the institutions conduct the learning and teaching process online. This pandemic also affected educational institution, which leads to online classes, webinars etc. (P \& Shahid, 2020). It does not only happen in the education sector, but some sectors are also suggested to work from home (WFH). It is a new concept that emerging to all sectors to work from home for the first time. In line with this condition, the research on seeing the readiness Economic and Social Sciences Faculty of Fajar University to apply e-learning in the learning and teaching process should be conducted whether this institution is ready or not.

Based on the above issues, the researcher wants to research how the preparation level of Economic and Social Sciences Faculty of Fajar University in the implementation of e-learning and what factors are still low and need to be improved in the implementation of elearning

\section{Literature Review \\ 2.1 E-Learning}

According to (Koohang \& Harman, 2005), e-learning is a means of providing all learning activities relevant to teaching and learning through various electronic media such as the internet, intranet, extranet, satellite TV, video or audio. According to Rusman (2012), e-learning is the process and activities of implementing e-learning, computer-based learning, virtual classrooms and digital classrooms. The materials for these e-learning activities are mostly provided through the Internet, intranet, videotapes or audio, satellite broadcast, interactive television and CD-ROM.

From the above definition, it can be concluded that elearning is a media to deliver learning process electronically that can be used by anyone, whether lecturers, students or the general public, and can be used anytime and anywhere using an Internet network.

\subsection{E-Learning Component}

Generally, there are three main components to build e-learning, namely:

a. E-learning System. It is software that visualizes the process of conventional teaching and learning process, class management, lesson or content creation, discussion forum, evaluating students score system, online examination, and all kinds that connected to the teaching and learning process management. This software system is well known as the Learning Management System (LMS).

b. E-learning content. The content of a class is delivered by using internet networking and other technology media. E-learning can cover formal and informal class.

c. Infrastructure e-learning. It is a Personal Computer (PC), computer network, and multimedia tools.

\subsection{E-Learning Readiness (ELR)}

According to Borotis \& Poulymenakou, e-learning readiness (ELR) is the mental or physical preparation of an organization to lead, act and create an online learning experience. According to Kaur and Abas, e-learning readiness is defined as a student's ability to use e-learning and multimedia systems to improve the quality of learning (Priyanto, 2009). According to (Saekow \& Samson, 2011), e-learning readiness is defined as the readiness of an organization to implement e-learning. This preparation includes mental preparation and physical preparation, namely preparation in terms of acceptance and infrastructure availability.

So it can be concluded that E-learning Readiness is the readiness in implementing e-learning from both sides which includes the physical and mental readiness of an organization for implementing e-learning, namely readiness from the side of acceptance and the side of infrastructure availability. E-learning Readiness describes the extent of an organization's readiness in several aspects to implement e-learning. Readiness is 
meant not only in terms of lecturers or students but also the readiness of the organization itself.

\subsection{E-Learning Readiness (ELR) Method}

To measure ELR, it needs a method. There are some methods from previous researchers such as Haney ELR Method, Seakow and Samson ELR method, and Aydin \& Tasci ELR method.

1. Haney ELR method. This method used seven questionnaire instruments in ELR evaluation: human source, learning management system, students, content, information technology, fund and vendor (Haney, 2002).

2. Seakow and Samson ELR method. This method aims to learn about the success in implementing e-learning in several universities in America. This method uses five factors before implementing e-learning, such as policy, technology, financial, human resources, and infrastructure(Saekow \& Samson, 2011).

3. Aydin \& Tasci ELR Method. Aydin \& Tasci developed an ELR model with four factors that can measure e-learning readiness. These factors are as follows:

\section{a. Technological factor}

Technology is one of the important factors in implementing e-learning in an organization to make it more effective. According to Rogers, technology has two components, namely hardware (hardware) and software (software). Hardware is the physical component of technology such as computers, printers, networks, scanners and servers. Furthermore, the software is a software component in the form of information that helps carry out specific tasks.

\section{b. Innovation Factor}

According to Rogers, that past experiences can affect readiness in using e-learning (Mailany, 2015). The innovation factor involves an examination of the user's past e-learning experiences. Furthermore, how the students and lecturers could face and defeat the obstacle to adapt the renewal changing.

\section{c. People factor}

People factors in the ELR Aydin \& Tasci model include experienced human resources (HR), elearning users, e-learning service providers, and the human ability to learn using technology. HR is a special energy that functions as a work input. This shows that HR plays an important role because HR will be both the subject and the object of e-learning based learning.

d. Self- development factor
Self-Development Factor in Aydin \& Tasci deals with e-learning budgets and managing time and confidence in personal development. According to Aydin \& Tasci, self-development factors can identify the willingness to implement e-learning in an organization. On the budget side, compared to conventional classes, the costs incurred for conducting e-learning are higher because the infrastructure necessary for the continuity of elearning also requires a significant investment. The budget for implementing e-learning in an organization requires good planning (Hendrastomo, 2008).

On managing time, e-learning can overcome the limitations of space and time between lecturers and students. The ability to manage time is needed so that elearning could run optimally. The learning process is not only done by campus but also outside the campus environment (Kusmana, 2011).

Each factor above must be formed from three sides, namely resources, skills, and attitudes as the table below. Aydin \& Tasci ELR Model used thirty questions formed from these factors and sides (Aydin \& Tasci, 2005).

Table 1. ELR Factor of Aydin \& Tasci Model

\begin{tabular}{|c|c|c|c|}
\hline & Resources & Skills & Attitude \\
\hline Technology & $\begin{array}{l}\text { Access to } \\
\text { computers } \\
\text { and the } \\
\text { internet }\end{array}$ & $\begin{array}{l}\text { Ability to use } \\
\text { computers } \\
\text { and the } \\
\text { internet }\end{array}$ & $\begin{array}{l}\text { Positive } \\
\text { attitude toward } \\
\text { the use of } \\
\text { technology }\end{array}$ \\
\hline Innovation & Barriers & $\begin{array}{l}\text { Ability to } \\
\text { adopt } \\
\text { innovation }\end{array}$ & $\begin{array}{l}\text { Openness to } \\
\text { innovation }\end{array}$ \\
\hline People & $\begin{array}{l}\text { - Educated } \\
\text { employee } \\
\text { - Experienced } \\
\text { HR } \\
\text { specialists } \\
\text { - An e- } \\
\text { learning } \\
\text { champion } \\
\text { - Vendors and } \\
\text { external } \\
\text { parties }\end{array}$ & $\begin{array}{l}\text { Ability to learn } \\
\text { via/ with } \\
\text { technology }\end{array}$ & \\
\hline $\begin{array}{l}\text { Self- } \\
\text { Development }\end{array}$ & Budget & $\begin{array}{l}\text { Ability to } \\
\text { manage time }\end{array}$ & $\begin{array}{l}\text { Belief in self- } \\
\text { development }\end{array}$ \\
\hline
\end{tabular}

\section{Method}

The approach used in this research is a descriptive quantitative approach. Descriptive research aims to describe or define existing phenomena, both in natural phenomena or human engineering (Sukmadinata, 2006).

This research model uses the Aydin \& Tasci 2005 ELR method of four factors, namely peoples, selfdevelopment, technology and innovation, that to measure e-learning implementation readiness. This template will provide a rating of the level of readiness to implement e- 
learning at any institutions. The Aydin \& Tasci ELR model was developed and adapted for use in this study.

This model can be applied before and after the application of e-learning. If it is before implementation, it gives a readiness score result. If applied after implementation, it provides results in an evaluation form for further application of e-learning. Then the e-learning readiness score, which is already known will be assessed which factors are still low or which are ready for elearning application.

The population used in this study was all the lecturers and students at Fajar University. The sample would be only for the permanent lecturers and active students in Economic and Social sciences Faculty of Fajar University. The sample took $10.8 \%$ of all populations. Moreover, the sample taking technique was accidental sampling due to ease to get the research sample which the researcher could take any sample at any time. This technique could fasten the process of researching (Sugiono, 2009). Accidental sampling is a technique to determine the sample based on the accidental. It means a sample accidentally meets with the researcher that perhaps fit to be a sample which matches to the source of data.

This research was conducted at the Economic and Social Sciences Faculty of Fajar University from June 2020 to August 2020. The researcher had 185 samples that 31 from lecturers and 154 from students.

\subsection{The Instrument of the Research}

\subsubsection{Questionnaire}

This study uses a questionnaire. The development of the researcher questionnaire was based on previous research namely the Aydin \& Tasci ELR model using 36 statements for lecturers and 19 questions for students which were formed from four factors namely peoples, personal development, technology and innovation.

This study uses the checklist method by checking $(\sqrt{ })$ the appropriate answer choices on the assessment sheet. Each question was rated using a Likert scale 1-5. The following scales are given:

$1=$ strongly disagree

$2=$ Disagree

$3=$ Neutral

$4=$ ok

$5=$ strongly agree

\subsubsection{SPSS 24.0}

To measure the validity and reliability test, SPSS 24.0 was used to comprehend the data. This instrument allows the researcher to avoid routine mathematical mistakes and produce accurate figures if input correctly.

After all, data were analyzed, the researcher tabulated the scores into the level of readiness based on the readiness measurement scale of Aydin \& Tasci model as figure 1 below. The rating scale consists of four categories, namely:

- Not ready, needs much work, is the lowest level of readiness, so more effort is needed to increase readiness.

- Not ready, needs some work, is a level of preparation which is a level below ready. At this level, a university needs a little more effort to be at the ready level.

- Ready, but needs a few improvements, is a level of preparation which is already classified as ready, but which still needs to be slightly improved. A university could develop an e-learning system, but it can be disrupted if there are unexpected problems.

- Ready, go ahead, is a level of preparation that is already classified as ready and quick to develop an elearning system.

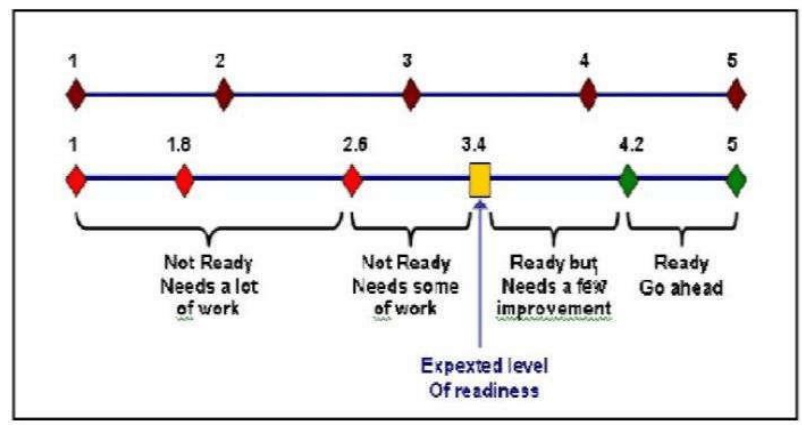

Figure 1. ELR Readiness Measurement Scale Source: (Aydin \& Tasci, 2005)

The average score of 3.41 is the minimum score for the readiness level to implement e-learning, so a score with an average value below 3.41 is considered unprepared for implementing e-learning.

Table 2. Score Range and categories of the ELR Aydin $\&$ Tasci models

Score range Category

\begin{tabular}{ll}
\hline $\mathbf{1} \leq \mathbf{x} \leq \mathbf{2 , 6}$ & Not ready, needs a lot of work \\
\hline $\mathbf{2 , 6}<\mathbf{x} \leq \mathbf{3 , 4}$ & Not ready, needs some of work \\
\hline $\mathbf{3 , 4}<\mathbf{x} \leq \mathbf{4 , 2}$ & $\begin{array}{l}\text { Ready, but needs a few } \\
\text { improvements }\end{array}$ \\
\hline $\mathbf{4 , 2}<\mathbf{x} \leq \mathbf{5}$ & Ready, go ahead! \\
\hline \multicolumn{2}{c}{ Source (Aydin \& Tasci, 2005) }
\end{tabular}

\section{Findings}

\subsection{Validity Test}

The validity and reliability test in analyzing the data used the SPSS 24.0 program with a significance level of $5 \%$, and 31 respondents (lecturers) obtained the value of 
$r_{\text {table }}=0.355$. The respondent (student) 154 people, obtained a value of $r_{\text {table }}=0.133$. The decision making criteria to determine the validity of the test if $r_{\text {count }}>r_{\text {tabel }}$ with a significance level of $5 \%$, it can be stated that the instrument item is valid, and vice versa if $r_{\text {count }}>r_{\text {table }}$ with a significant level of $5 \%$ then the item is invalid.

After looking for the validity results with the testing criteria, if $r_{\text {count }}$ is greater than $r_{\text {table }}$ with a significance level of $5 \%$, it can be stated that the instrument item is valid, and vice versa if rcount is less than rtable with a significant level of $5 \%$ then the instrument item is invalid. Moreover, from the test results, the results show that 37 instrument items for lecturers and 19 instruments for students have a value of $r_{\text {results }}>r_{\text {table. }}$ It is proven that the research instrument items are declared valid. For more details, see the table below.

Table 3. Case Processing Summary

\begin{tabular}{llrr} 
& & $\mathbf{N}$ & \multicolumn{1}{c}{$\%$} \\
\hline \multirow{2}{*}{ Cases } & Valid & 31 & 100.0 \\
\cline { 2 - 4 } & Excluded $^{\mathrm{a}}$ & 0 & .0 \\
\cline { 2 - 4 } & Total & 31 & 100.0
\end{tabular}

a. Listwise deletion based on all variables in the procedure.

Tabel 4. Case Processing Summary

\begin{tabular}{clrr}
\hline & & $\mathrm{N}$ & \multicolumn{2}{c}{$\%$} \\
\hline \multirow{2}{*}{ Cases } & Valid & 154 & 100.0 \\
\cline { 2 - 4 } & Excluded $^{\mathrm{a}}$ & & .0 \\
\cline { 2 - 4 } & Total & 154 & 100.0 \\
\hline
\end{tabular}

\subsection{Reliability Test}

Several valid items then test the level of reliability. Reliability would show the reliability level if the instrument used can produce almost the same data at different times and places. The criteria for testing the reliability test is if $r_{\text {count }}$ is greater than $r_{\text {table }}$ with a significance level of $5 \%(0.05)$ it can be stated that the measuring instrument is reliable. Vice versa if $r_{\text {count }}$ is less than $r_{\text {table }}$ then the measuring instrument is not reliable. And the results of testing the reliability test can be seen in tables 5 and 6 :

Table 5. Results of the validity test of the lecturers' questionnaire

$r_{\text {table }} r_{\text {count }}($ Cronbach's Alpha $) \quad$ Description
0.300
0.751
Reliable

Based on table 5, the reliability test result for lecturers' questionnaire shows reliable due to $r_{\text {count }}$ is 0.751 that is greater than $r_{\text {table }}$ that is 0.300 . If $r_{\text {count }}$ is greater than $r_{\text {table, }}$ it can be stated that the measuring instrument is reliable.

Table 6. Results of the validity test of the students' questionnaire

\begin{tabular}{ccc}
\hline $\mathrm{r}_{\text {table }}$ & $\mathrm{r}_{\text {count }}($ Cronbach's Alpha $)$ & Description \\
& & \\
\hline $\mathbf{0 . 1 5 8}$ & 0.751 & Reliable
\end{tabular}

Based on table 6, the reliability test result for lecturers' questionnaire shows reliable due to $r_{\text {count }}$ is 0.751 that is greater than $r_{\text {table }}$ that is 0.158 . If $r_{\text {count }}$ is greater than $r_{\text {table, }}$ it can be stated that the measuring instrument is reliable. This finding research is a form of internal evaluation and future planning for this institution that aims to know the preparation level of Economic and Social Sciences Faculty of Fajar University in the implementation of e-learning and factors are still low and need to be improved in the implementation of e-learning.

The questionnaire results of the questionnaire distribution for Economic and Social Sciences Faculty of Fajar University are presented in the table below. The questionnaire for this study consists of 37 questions for lecturers and 19 questions for students with alternative responses "Strongly agree" with a score of 5, "agree" with a score of 4, "Neutral" with a score of 3, "Disagree" with a score of 2 and "Strongly disagree" with a score of 1.

Table 7. Results of the questionnaire distribution

\begin{tabular}{lcc}
\hline \multicolumn{1}{c}{ Study Program } & $\mathrm{r}_{\text {count }}$ & Total \\
\hline English literature & Lecturers & 31 \\
International Relations & & \\
Accounting D3 & \\
S1 Accounting & \\
Communication Studies & & \\
Management & & \\
Tourism Development & &
\end{tabular}

\begin{tabular}{lll}
\cline { 2 - 2 } & Students & 154 \\
\hline Total & & 185
\end{tabular}

Based on table 7, the number of samples is 185 that have filled distributed questionnaires. Respondents who filled out the questionnaire were 31 lecturers and 154 
students. The recapitulation of the results of filling out the lecturer questionnaire can be seen in table 8 below.

\begin{tabular}{ccl}
\hline \multicolumn{2}{c}{ Table 8. ERL score results for each factor (Lecturer) } \\
\hline ERL Factor & $\begin{array}{c}\text { ERL } \\
\text { score }\end{array}$ & \multicolumn{1}{c}{ Description } \\
\hline People Factor & 3.70 & $\begin{array}{l}\text { Ready, but needs a few } \\
\text { improvements }\end{array}$ \\
\hline $\begin{array}{c}\text { Technology } \\
\text { Factor }\end{array}$ & 3.70 & $\begin{array}{l}\text { Ready, but needs a few } \\
\text { improvements }\end{array}$ \\
\hline $\begin{array}{c}\text { Self- } \\
\text { development } \\
\text { Factor }\end{array}$ & 3.20 & $\begin{array}{l}\text { Not ready, needs some } \\
\text { of work }\end{array}$ \\
\hline $\begin{array}{c}\text { Innovation } \\
\text { Factor }\end{array}$ & 3.70 & $\begin{array}{l}\text { Ready, but needs a few } \\
\text { improvements }\end{array}$ \\
\hline $\begin{array}{c}\text { Total ERL } \\
\text { Roto fow }\end{array}$ & 3.60 & $\begin{array}{l}\text { Ready, but needs a few } \\
\text { improvements }\end{array}$ \\
\hline
\end{tabular}

In table 8, it shows an ELR score result for lecturers. 31 lecturers from 7 program studies have answered the given questionnaires and result showing the readiness of lecturers to implement e-learning in teaching process because a score of ELR $<\bar{x}=3.60>3.41$. If ERL score is greater than 3.41 , it means showing the readiness and vice versa. Self-development factor is the only factor indicates not ready and needs some of the work. However, the rest of the factors like people, technology, and innovation factors designate readiness but needs a few improvements.

Table 9. ERL score results for each factor (Students)

\begin{tabular}{ccl} 
ERL Factor & $\begin{array}{c}\text { ERL } \\
\text { score }\end{array}$ & \multicolumn{1}{c}{ Description } \\
\hline People Factor & 3.80 & $\begin{array}{l}\text { Ready, but needs a few } \\
\text { improvements }\end{array}$ \\
$\begin{array}{c}\text { Technology } \\
\text { Factor }\end{array}$ & 3.20 & $\begin{array}{l}\text { Not ready, needs some } \\
\text { of work }\end{array}$ \\
$\begin{array}{c}\text { Self- } \\
\text { development } \\
\text { Factor }\end{array}$ & 3.50 & $\begin{array}{l}\text { Ready, but needs a few } \\
\text { improvements }\end{array}$ \\
$\begin{array}{c}\text { Innovation } \\
\text { Factor }\end{array}$ & 3.20 & $\begin{array}{l}\text { Not ready, needs some } \\
\text { of work }\end{array}$ \\
\hline ERL Total & 3.40 & $\begin{array}{l}\text { Not ready, needs some } \\
\text { of work }\end{array}$ \\
\hline
\end{tabular}

Based on table 9 above, the ELR total score for students is $\bar{x}=3.40<3.41$. This score means the students are not ready and need some work to implement elearning in the learning process. Even though in technology and innovation, factors display un-readiness, but in the factor of people and self-development show the readiness even needs a few improvements.

Tabel 10. ERL Final Score Result

\begin{tabular}{ccc}
\hline ERL Factor & $\begin{array}{l}\text { Skor } \\
\text { ERL }\end{array}$ & Keterangan \\
\hline Lecturer & 3.60 & $\begin{array}{l}\text { Ready, but needs a few } \\
\text { improvements }\end{array}$ \\
\hline
\end{tabular}

\begin{tabular}{ccl}
\hline Students & 3.40 & $\begin{array}{l}\text { Not ready, needs } \\
\text { some of work }\end{array}$ \\
\hline ERL Total & 3.50 & $\begin{array}{l}\text { Ready, but needs a few } \\
\text { improvements }\end{array}$ \\
\hline
\end{tabular}

Based on table 10 above, it indicates that the Faculty of Economic and Social Sciences of Fajar University is ready to implement e-learning in teaching and learning process.

\section{Discussion \\ 5.1 The Readiness Level}

The score of ELR obtained from lecturers in table 8 is $\bar{x}=3.60>3.41$. If 3.60 is greater than 3.41 , it means lecturers from Economic and Social Sciences Faculty Fajar University belongs to the ready category to implement e-learning in teaching process even though it needs a few improvements. Improvements were made to the ELR factors that had low scores, for example, the self-development factors that had an ELR score of $3.20<$ 3.40 , which was not ready factors that needed some of the work. Although there is a self-development factor that is not ready, in people factors, technology, and innovation have a score of ELR $\bar{x}<3.70$, which means belongs to ready category even requires a few improvements.

In table 9, students have a score of ELR $<\bar{x}=3.40$ $<3.41$. The score on the people factor is $\bar{x} 3.41<3.80$ and self-development has a value of $3.41<3.50$, this shows that in these factors peoples and student selfdevelopment are ready to implement e-learning in the learning process even though it requires a little improvement. In contrast to people factors and selfdevelopment, technology and innovation factors have a score of ELR $<\bar{x}=3.20<3.41$, which means that these factors are not ready and need a little improvement to reach the ready level.

From overall score for ELR both lecturers and student in table 10 , it has $\bar{x}=3.50<3.41$. This final score is to see how the readiness of this institution to implement e-learning in teaching and learning process. The score obtained indicated that the readiness in implementing elearning is in a ready category but needs a few improvements.

Based on this discussion, it can be seen that the level of readiness for implementing e-learning according to the scores obtained from the lecturers and students of Economic and Social Sciences Faculty Fajar University as follows:

a. The results obtained from the lecturers are in the ready category and require a few improvements in people factors, technology, and innovation. In contrast, the self-development factor shows that the factors are not ready and need a few improvements. 
b. The score obtained from students is that they are not ready for e-learning implementation and need a few improvements. However, the people factor and selfdevelopment are showing ready results but need a few improvements.

c. Based on the final results of the ELR assessment score in Aydin \& Tasci model in Table 10, it can be seen that overall ( lecturers and students) the Economic and Social Sciences Faculty Fajar University has an ELR score $\bar{x}=3.50$ which means that the ELR score is $3.41<\bar{x}<3.50$. This shows that the Faculty of Economic and Social Sciences Fajar University is ready to implement e-learning but still needs a few improvements on each of its factors, and pays more attention to the ELR factors with the low score. Improvement was also made to increase the low ELR score to improve the quality of using elearning in the teaching and learning process.

\subsection{Future Planning}

Based on the final score in Table 10, this institution is ready to implement e-learning in teaching and learning process even though it needs a few improvements. To achieve ready category, it needs some future planning as follow;

a. People factors for lecturers and students

- Provide e-learning training and socialization so that teachers and students have the expertise and experience in using e-learning. Moreover, teachers who already have the expertise and experience should take advantage of online learning in the learning process.

- Increase the relationship between students and students so that they can work together to complete homework using e-learning.

b. Technology factor toward lecturers and students

- There is a need for improvement in the relationship between students and lecturers to work together during the learning process with e-learning so that elearning can be appropriately utilised.

- There is a need to improve the relationship between lecturers and institutional operators as administrators to work together so that e-learning can be appropriately managed.

c. Self-development factor toward lecturers and students.

- There is a need to increase the allocation of time, which means that the time spent learning to accept changes in the learning process still needs to be improved.
- The funds for implementing e-learning at the Faculty should be discussed on increasing budget planning and the implementation of e-learning during meetings. Budget planning can show that the funding source of the Faculty itself is sufficient or insufficient.

- Careful budget planning will deliver the results of implementing good e-learning with maximum funds. Faculties are encouraged to provide financial support and establish budget details to implement, inter alia, the provision of Internet network infrastructure, development of e-learning applications, maintenance or repair of e-learning and fund allocation for managers or administrators who manage e-learning so that it can be implemented properly

d. Innovation factor towards lecturer and students

There is a need to develop resources capable of facing and overcoming obstacles and the capacity of teachers and students to adapt to renewal changes through training and sharing sessions.

Based on the explanation above, the researcher could predict the future of this institution to face significant data era to become leading university to conduct teaching and learning process online without any obstacles from both lecturers and students if those future planning components accomplished.

\section{Conclusion}

Based on the results of the research and discussion on the level of readiness for the implementation of elearning at the Economic and Social Sciences Faculty Fajar University, it can be concluded that:

1) The level of preparation for the implementation of e-learning to lecturers at the Economic and Social Sciences Faculty Fajar University obtained $\bar{x}=$ 3.60. This shows that lecturers are ready to implement e-learning, but still need a few improvements on each of its factors. Furthermore, pay more attention to the ELR factors with the least value, namely the self-development factors.

2) While the results obtained for students at the Economic and Social Sciences Faculty Fajar University are $\bar{x}=3.40$. These results show if the students are not ready to implement e-learning in the learning process. Even if there are technological and innovation factors that results are not ready, in terms of people and self-development factors, students are ready to implement e-learning even if it needs a few improvements. 
3) Final score result both lecturers and students indicated that this institution is ready to implement e-learning in teaching and learning process even.

\section{Suggestion}

The suggestions that can be given based on the research carried out are as follows: I am adding factors as a component of Aydin \& Tasci ELR model questionnaire to provide more optimal measurement results depending on the research location. Determination of categories for more specified factors to provide a more precise evaluation result. It is expected that the Economic and Social Sciences Faculty Fajar University can make improvements and assessments to increase the readiness to implement e-learning and pay more attention to the factors that are still low or least valuable, especially on student final results.

\section{References}

Al Fajri, Syaifudin. (2018). Pengukuran Tingkat Kesiapan Penerapan E-Learning di Smkn 1 Banyumas. Undergraduate thesis, Universitas Negeri Yogyakarta.

Angraini, \& Suryadi, D. (2015). Pengukuran Tingkat Kesiapan Penerapan E-LEarning Menggunakan TRI (Technology Readiness Index), Studi Kasus: UIN Suska Riau. Jurnal Sistem Informasi, 5(3), 237-241.

Aydin, C. H., \& Tasci, D. (2005). Measuring readiness for e-learning: Reflections from an emerging country. Journal of Educational Technology \& Society, 8(4), 244-257.

Arikunto. (2010). Prosedur Penelitian: Suatu Pendekatan Praktik Edisi Revisi. Jakarta: Rineka Cipta.

Dinata, Nana Syaodih Sukma. (2006). Metode Penelitian Pendidikan. Bandung: PT Remaja Rosdakarya.

Haney, D. (2002). Assessing organizational readiness for e-learning: 70 questions to ask. Performance improvement, 41(4), 8-13.

Hendrastomo, G. (2008). Dilema Dan Tantangan Pembelajaran E-Learning. Majalah Ilmiah Pembelajaran, 4(1), 24-38.

Koohang, A., \& Harman, K. (2005). Open Source: A Metaphor for E-Learning. Informing Science Journal, 8, 75-86.

Kusmana, A. (2011). E-Learning Dalam Pembelajaran. Lentera Pendidikan, 14(1), 35-51.
Mailany, Masrura. (2015). Analisis Faktor-Faktor Pengukuran Tingkat Kesiapan Implementasi ELearning di Perguruan Tinggi Fakultas Ilmu Komputer Program Studi Magister Teknologi Informasi. Universitas Indonesia. 27-28.

Shareena, P., \& Shahid, M. (2020). Work from home during COVID-19: Employees perception and experiences. Global journal for Research Analysis, 9(5).7-10.

Putri, S. E., Hamuddin, B., Nursafira, M. S., \& Derin, T. (2020). Discourse Analysis in E-Learning-Based Course Using Moodle Platform : An Experimental Design. Journal of Research and Innovation in Language, 2(1), 19-26.

Priyanto. (2009). Model E-learning Readiness Sebagai Strategi Pengembangan ELearning" International Seminar Proceedings, Information and Communication Technology (ICT) In Education. Graduate School. 267-275.

Rahamma, T., \& Nadjib, M. (2015). Intensitas Penggunaan E-Learning Dalam Menunjang Pembelajaran Mahasiswa Program Sarjana (S1) Di Universitas Hasanuddin. Jurnal Komunikasi KAREBA, 4(4), 387-398.

Rusman, Deni Kurniawan, dan Cepi Riyana. (2012). Pembelajaran Berbasis Teknologi Informasi dan Komunikasi Mengembangkan Profesionalitas Guru. Jakarta: Penerbit Rajawali Pers.

Saekow, A., \& Samson, D. (2011). A study of e-learning readiness of Thailand's higher education comparing to the United States of America (USA)'s case. International Conference on Computer Research and Development (ICCRD), Shanghai, 287-291. https://doi.org/10.1109/ICCRD.2011.5764134

Setyosari, Punaji. (2013). Metodelogi Penelitian Pendidikan dan Pengembangan edisi IV. Jakarta: Prenadamedia Group.

Sugiyono. (2009). Metodologi Penelitian Petunjuk Praktis untuk Peneliti Pemula. Yogyakarta: UGM Press.

Sugiyono. (2019). Metodologi Penelitian kuantitatif, kualitatif dan $R \& D$. Bandung: alfabeta. 